\title{
UJI AKTIVITAS ANTIMIKROBA EKSTRAK ETANOL ORGANISME LAUT SPONS Ianthella basta TERHADAP BEBERAPA MIKROBA PATOGEN
}

\author{
Syifa Sari Katili' ${ }^{1)}$, Defny S. Wewengkang ${ }^{1)}$, Henki Rotinsulu ${ }^{1)}$ \\ ${ }^{1)}$ Program Studi Farmasi FMIPA UNSRAT Manado, 95115
}

\begin{abstract}
Sponges are multicellular metazoa animals belonging to the Porifera phylum, which has a different structure from other metazoans. The purpose of this study was to determine whether ethanol extracts from the marine organism sponge Ianthella basta have antimicrobial activity against several pathogenic microbes Escherichia coli, Staphylococcus aureus, Pseudomonas aeruginosa and Candida albicans. The extraction method used is maceration with $96 \%$ ethanol solvent. The method used is the Diffusion Method (Disc Diffusion Kirby and Bauer). The antimicrobial activity test uses a $6 \mathrm{~mm}$ paper disc with $50 \mu \mathrm{L}$ absorption per disc. The results of crude ethanol extract of Ianthella basta sponge from all test microbes, namely Escherichia coli, Staphylococcus aureus, Pseudomonas aeruginosa and Candida albicans, were seen to provide the greatest inhibitory activity against Staphylococcus aureus bacteria with an average of inhibitory zone of $7.00 \mathrm{~mm}$ categorize as intermediate The results obtained showed that the crude extract of the sponge Ianthella basta has antimicrobial activity because it can inhibit the growth of Staphylococcus aureus, Escherichia coli and Candida albicans microbes even though the inhibition zone is categorized as intermediate.
\end{abstract}

Keywords: Ianthella basta, antimicrobial, Staphylococcus aureus, Escherichia coli, Pseudomonas aeruginosa, Candida albicans.

\begin{abstract}
ABSTRAK
Spons adalah hewan metazoa multiseluler tergolong ke dalam filum Porifera, yang memiliki perbedaan struktur dengan metazoan lainnya. Tujuan penelitian ini ialah untuk mengetahui apakah ekstrak etanol dari organisme laut spons Ianthella basta memiliki aktivitas antimikroba terhadap beberapa mikroba patogen Escherichia coli, Staphylococcus aureus, Pseudomonas aeruginosa dan Candida albicans. Metode ekstraksi yang digunakan adalah maserasi dengan pelarut etanol 96\%. Metode yang digunakan yaitu Metode Difusi (Disc Diffusion Kirby and Bauer). Pengujian aktivitas antimikroba ini menggunakan kertas cakram (paper disc) berukuran $6 \mathrm{~mm}$ dengan daya serap $50 \mu \mathrm{L}$ tiap cakram. Hasil ekstrak kasar etanol Spons Ianthella basta dari semua mikroba uji yaitu Escherichia coli, Staphylococcus aureus, Pseudomonas aeruginosa dan Candida albicans, terlihat yang memberikan daya hambat paling besar terdapat pada bakteri Staphylococcus aureus dengan jumlah rata - rata zona hambat yaitu $7,00 \mathrm{~mm}$ dengan kategori sedang. Hasil penelitian yang diperoleh menunjukkan bahwa ekstrak kasar dari Spons Ianthella basta memiliki aktivitas antimikroba karena mampu menghambat pertumbuhan mikroba uji Staphylococcus aureus, Escherichia coli dan Candida albicans walaupun dengan zona hambat yang dikategorikan sedang.
\end{abstract}

Kata Kunci : Ianthella basta, antimikroba, Staphylococcus aureus, Escherichia coli, Pseudomonas aeruginosa, Candida albicans. 


\section{PENDAHULUAN}

Spons adalah hewan metazoa multiseluler tergolong ke dalam filum Porifera, yang memiliki perbedaan struktur dengan metazoan lainnya. Spons mencari makan dengan menghisap dan menyaring air melalui seluruh permukaan tubuhnya secara aktif (Romimohtarto dan Juwana 1999). Spons terdiri dari 850 jenis, terbagi menjadi tiga kelas besar, yaitu Calcarea, Demospongiae dan Hexactinellida (Thakur dan Müller 2004).

Seperti spons pada umumnya, spons Ianthella basta mempunyai morfologi dengan bentuk tubuh yang berpori dan permukaan yang keras seperti batu. Selain itu, Ianthella basta juga dapat menyerap oksigen dari air melalui proses difusi.Secara khusus, individu dari Ianthella basta ditemukan dalam berbagai morfotipe warna (kuning, coklat, hijau, biru atau ungu) (Webster et al., 2010).

$\begin{aligned} \text { Spons } & \text { Ianthella basta dapa } \\ \text { menghasilkan } & \text { senyawa khusus yaitu }\end{aligned}$
bastadin. Dua morfotipe warna dominan pada Ianthella basta dicirikan oleh profil kimia dan mikroba yang berbeda dengan hubungan silsilah yang belum terselesaikan yang disimpulkan pada tingkat molekuler. Morfotipe kuning, yang mengandung kelas senyawa bastadin, didominasi oleh dua strain yang merupakan anggota dari Alpha dan Gammaproteobacteria. Morfotipe ungu yang mengandung bastadin serta dua araplysillin juga didominasi oleh Alpha dan Gammaproteobacteria, tetapi galur dominan pada spons ungu menunjukkan sedikit variasi urutan $(1 \%)$ terhadap galur dominan pada spons kuning. Selain itu, morf warna ungu mengandung perwakilan kecil dari Cyanobacteria, Verrucomicrobia dan Chloroflexi (Marnie et al., 2011).

\section{METODOLOGI PENELITIAN}

\section{Waktu dan Tempat Penelitian}

Penelitian ini di laksanakan pada bulan April 2019 - Juni 2019. Tempat pengambilan sampel dilakukan di perairan Ponteng, Minahasa Tenggara dan untuk preparasi sampel, pengamatan dilakukan di Laboratorium Penelitian Farmasi Lanjutan (Farmakognosi Fitokimia dan Laboratorium Mikrobiologi Farmasi) Program Studi Farmasi, Fakultas Matematika dan Ilmu Pengetahuan Alam, Universitas Sam Ratulangi.

\section{Bentuk Penelitian}

Penelitian ini merupakan penelitian dengan menggunakan metode eksperimental laboratorium yang akan menguji aktivitas antibakteri ekstrak kasar dari Spons Ianthella basta.

\section{Alat dan Bahan}

a. Alat

Alat yang digunakan dalam penelitian ini yaitu scuba diving, sarung tangan, zipper bag, gunting, kamera, wadah kaca, pisau, Erlenmeyer (Pyrex), timbangan analitik, gelas ukur (Pyrex), gelas kimia (Pyrex), cawan petri, autoklaf (autoklaf KT-30s), spatula, pinset, pembakar spritus, pipet tetes, mikro tubes, batang pengaduk, Laminary air flow (Clean Bench), rak tabung reaksi, tabung reaksi, lemari pendingin, incubator incucell ( $\mathrm{N}$ - Biotek), cakram (paper disc), mikropipet, digital caliper, vial, oven, jarum ose, vortex dan jas lab.

b. Bahan

Bahan yang digunakan yaitu Spons Ianthella basta, bakteri Escherichia coli 
ATCC 25922, bakteri Staphylococcus aureus ATCC 25923, bakteri Pseudomonas aeruginosa ATCC 25924 dan jamur Candida albicans ATCC 10231, etanol 96\%, aquadest, Pepton, Ekstrak Beef, NaCl, Agar, Paper Disc, Kloramfenikol Paper Disc, label, spidol permanen, tissue, aluminium foil, kertas saring, dan kapas.

\section{Prosedur Penelitian}

\section{Ekstraksi}

Spons Ianthella basta sebanyak $288 \mathrm{~g}$ diekstrak dengan cara maserasi. Sampel dibersihkan dari bahan pengotor, dipotong kecil - kecil dimasukkan ke dalam wadah, kemudian direndam dengan pelarut etanol $96 \%$ sampai sampel terendam semuanya, dikocok- kocok lalu dibiarkan selama 1x24 jam. Sampel yang sudah direndam kemudian disaring menggunakan corong dan kertas saring dan menghasilkan filtrat 1 dan debris 1 . Debris 1 direndam kembali dengan etanol 96\% sampai terendam semuanya, debris dikocok - kocok dan dimaserasi selama 1x24 jam. Diulangi cara yang sama sampai memperoleh 3 filtrat dan 3 debris. Campurkan filtrat 1, 2, dan 3 yang diperoleh menjadi satu. Filtrat dievaporasi menggunakan oven dengan suhu $40^{\circ} \mathrm{C}$ hingga memperoleh ekstrak kasar spons Ianthella basta dan timbang dengan menggunakan timbangan analitik. Ekstrak kasar etanol spons Ianthella basta sebanyak 22,2 g, selanjutnya ekstrak kasar etanol digunakan dalam pengujian daya hambat antimikroba.

\section{Sterilisasi dan Pembuatan Media Sterilisasi Alat}

Alat-alat gelas yang digunakan dalam penelitian aktivitas antimikroba ini disterilkan terlebih dahulu dengan menggunakan autoklaf pada suhu $121{ }^{\circ} \mathrm{C}$ selama 15 menit, pinset dibakar dengan pembakaran di atas api langsung dan media disterilkan di autoklaf pada suhu $121^{\circ} \mathrm{C}$ selama 15 menit (Ortez, 2005).

\section{Pembuatan Media Cair BI}

Pepton 0,5 g, beef extract 0,3 g, natrium klorida $0,3 \mathrm{~g}$ dan akuades sebanyak $100 \mathrm{ml}$ diaduk sampai homogen kemudian disterilkan dalam autoklaf pada suhu $121^{\circ} \mathrm{C}$ selama 15 menit dan setelah itu didinginkan. Setelah dingin, media cair B1 di tutup dengan aluminium foil (Dwijendra et al, 2014).

\section{Pembuatan Media Uji}

Pepton 0,5 g, beef extract 0,3 g, natrium klorida $0,3 \mathrm{~g}$, agar $1,5 \mathrm{~g}$ dan akuades sebanyak $100 \mathrm{ml}$ diaduk sampai homogen kemudian disterilkan di autoklaf pada suhu $121^{\circ} \mathrm{C}$ selama 15 menit (Dwijendra et al., 2014).

\section{Pembuatan Larutan Uji}

Larutan uji dibuat dengan cara $1 \mathrm{mg}$ ekstrak kasar Spons Ianthella basta. dilarutkan dalam $200 \mu \mathrm{L}$ metanol dan dikocok hingga homogen menggunakan vortex. (Ortez, 2005).

\section{Pembuatan Kontrol Positif dan Kontrol Negatif}

Kontrol positif dalam pengujian aktivitas antimikroba ini menggunakan kloramfenikol paper disc. Kontrol negatif yang digunakan dalam penelitian ini yaitu menggunakan pelarut metanol, dengan cara membuat larutan stok metanol dengan mengambil sebanyak $200 \mu \mathrm{L}$ metanol kemudian di totolkan pada paper disc.

\section{Pengujian Aktivitas Antimikroba}

Metode yang digunakan dalam penelitian ini yaitu metode difusi agar 
(disc diffusion Kirby and Bauer). Pada pengujian aktivitas antimikroba ini, cakram (paper disc) yang digunakan berukuran $6 \mathrm{~mm}$ dengan daya serap $50 \mu \mathrm{L}$ tiap cakram. Sebanyak $300 \mu \mathrm{L}$ mikroba yang telah dikultur, dipipet dan diinokulasi pada $30 \mathrm{ml}$ media agar lalu diaduk hingga homogen dan kemudian dituangkan ke dalam cawan petri dan tunggu sampai media agar mengeras. Kemudian, larutan uji yang telah disiapkan ditotolkan pada masing-masing cakram dengan menggunakan mikropipet. Setelah agar mengeras, kertas cakram yang telah ditotolkan sampel Spons Ianthella basta, kontrol positif dan kontrol negatif diletakkan ke dalam cawan petri dengan menggunakan pinset. Selanjutnya, cawan petri diberi label dan diinkubasi dalam inkubator pada suhu $37^{0} \mathrm{C}$ selama 1 x 24 Jam (Ortez, 2005).

\section{Pengamatan dan Pengukuran Diameter Zona Hambat}

Pengamatan dilakukan setelah 24 jam masa inkubasi. Daerah pada sekitar cakram menunjukkan kepekaan mikroba terhadap antibiotik atau bahan antimikroba yang digunakan sebagai bahan uji yang dinyatakan dengan diameter zona bening. Diameter zona bening diukur menggunakkan digital caliper. Kemudian zona bening yang telah diukur, dikategorikan berdasarkan pedoman Davis dan Stout (1971).

\section{HASIL DAN PEMBAHASAN \\ Ekstraksi}

Sampel spons Ianthella basta yang dikoleksi dari perairan Ponteng dipotong kecil-kecil, kemudian dimasukkan ke dalam wadah. Dipotong kecil-kecil untuk memperluas ukuran permukaan sampel, semakin luas permukaan sampel maka lebih banyak senyawa aktif akan tertarik dari sampel ke dalam pelarut (Kristanti et al., 2008). Sampel spons Ianthella basta selanjutnya diekstraksi dengan metode maserasi. Metode maserasi digunakan karena cara pengerjaannya yang mudah dikerjakan dengan menggunakan peralatan yang sederhana, tidak menggunakan pemanasan dan dapat menarik senyawa senyawa aktif dari sampel dengan maksimal. Perendaman sampel dalam maserasi dapat membuat dinding sel dari sampel pecah dan membuat senyawasenyawa yang ada dalam sampel yang terdapat dalam sitoplasma akan tertarik oleh pelarut. Dinding sel pecah di karenakan adanya perbedaan konsentrasi di dalam dan di luar sel. Konsentrasi di luar sel lebih tinggi dibandingkan konsentrasi di dalam sel yang rendah sehingga dinding sel pecah karena tidak bisa menahan tekanan dari perbedaan konsentrasi (Harborne, 1996).

Pada proses maserasi dilakukan pengocokan agar pelarut dapat melarut ke dalam sampel dan akan masuk ke ronggarongga sampel karena dalam keadaan diam selama maserasi menyebabkan turunnya perpindahan bahan aktif. Etanol 96\% lebih mudah masuk ke dalam sel simplisia sehingga ekstrak yang dihasilkan lebih kental. Senyawa aktif dalam sampel agar tertarik semua ke dalam pelarut dilakukan remaserasi dengan penggantian pelarut sebanyak tiga kali dengan pelarut etanol. Maserasi agar lebih efisien dilakukan berulang kali dibandingkan hanya dilakukan sekali (Mujipradhana, 2018). Pelarut yang digunakan yaitu etanol, digunakan pelarut etanol $96 \%$ karena didasarkan pada tingkat keamanan, kemudahan saat diuapkan, ekonomis, 
mudah bercampur dengan air serta sifatnya yang mampu melarutkan hampir semua zat, baik yang bersifat polar, semipolar, dan nonpolar (Sulastri et al., 2015).

Hasil ekstrak Spons Ianthella basta selanjutnya diuapkan menggunakan oven dengan suhu $40^{\circ} \mathrm{C}$, penguapan ekstrak ini dimaksudkan agar air dan pelarut yang tersisa dalam ekstrak akan menguap. Menggunakan suhu $40^{\circ} \mathrm{C}$ bertujuan untuk tetap menjaga senyawa bioaktif dalam filtrat karena biasanya senyawa-senyawa bioaktif rentan terhadap suhu tinggi (Kowal

Tabel 1. Rendemen ekstrak kasar Etanol

Ianthella basta

\begin{tabular}{llll}
\hline No. & Sampel & $\begin{array}{l}\text { Randemen } \\
(\boldsymbol{\%})\end{array}$ & $\begin{array}{l}\text { Warna } \\
\text { Sampel }\end{array}$ \\
\hline 1. & Ekstral & 7,70 & Coklat \\
& Etanol & & \\
\hline
\end{tabular}

et al., 2018).

Uji Aktivitas Antimikroba Spons Ianthella basta

Pengujian aktivitas antimikroba dari spons Ianthella basta dilakukan pada bakteri Escherichia coli dan Pseudomonas aeruginosa mewakili bakteri Gram negatif, bakteri Staphylococcus aureus yang mewakili bakteri Gram positif dan Candida albicans yang mewakili Jamur menggunakan Metode difusi agar (difusi Kirby-Bauer yang telah dimodifikasi). Masing - masing ekstrak kasar diujikan pada masing - masing bakteri dan jamur. Metode difusi digunakan karena prosedurnya yang sederhana, mudah dan praktis untuk dikerjakan dan dapat melihat sensitivitas berbagai jenis mikroba terhadap antimikroba (Mpila, 2012). Penggunaan mikroba hal ini bertujuan melihat apakah ekstrak spons Ianthella basta memiliki aktivitas antimikroba terhadap mikroba patogen pada tubuh manusia dan untuk mengetahui spektrum dari aktivitas antimikroba spons Ianthella basta memiliki spektrum luas (membunuh banyak jenis mikroba) atau spektrum sempit (membunuh salah satu mikroba).

Tabel 2. Hasil rata-rata Aktivitas Antimikroba

\begin{tabular}{|c|c|c|c|c|}
\hline $\begin{array}{l}\text { Mikroorga } \\
\text { nisme }\end{array}$ & $\begin{array}{l}\text { Percob } \\
\text { aan }\end{array}$ & $\begin{array}{l}\text { Ekstr } \\
\text { ak } \\
\text { Etan } \\
\text { ol }\end{array}$ & $\mathbf{K}+$ & K- \\
\hline \multirow[t]{4}{*}{ E. coli } & I & 6,50 & \multirow{4}{*}{$\begin{array}{l}14, \\
00\end{array}$} & \multirow{4}{*}{$\begin{array}{l}0,0 \\
0\end{array}$} \\
\hline & II & 6,50 & & \\
\hline & III & 6,40 & & \\
\hline & $X$ & 6,47 & & \\
\hline \multirow[t]{4}{*}{ S. aureus } & I & 7,00 & \multirow{4}{*}{$\begin{array}{l}18, \\
05\end{array}$} & \multirow{4}{*}{$\begin{array}{l}0,0 \\
0\end{array}$} \\
\hline & II & 7,00 & & \\
\hline & III & 7,00 & & \\
\hline & $X$ & 7,00 & & \\
\hline \multirow{4}{*}{$\begin{array}{l}P . \\
\text { aeruginosa }\end{array}$} & I & 0,00 & \multirow{4}{*}{$\begin{array}{l}13, \\
00\end{array}$} & \multirow{4}{*}{$\begin{array}{l}0,0 \\
0\end{array}$} \\
\hline & II & 0,00 & & \\
\hline & III & 0,00 & & \\
\hline & $X$ & 0,00 & & \\
\hline \multirow[t]{4}{*}{ C. albicans } & I & 6,40 & \multirow{4}{*}{$\begin{array}{l}16, \\
05\end{array}$} & \multirow{4}{*}{$\begin{array}{l}0,0 \\
0\end{array}$} \\
\hline & II & 6,50 & & \\
\hline & III & 6,60 & & \\
\hline & $X$ & 6,50 & & \\
\hline
\end{tabular}


Hasil yang diperoleh dalam uji aktivitas antimikroba dilakukan pengamatan selama $1 \times 24$ jam masa inkubasi dengan 3 kali penggulangan untuk masing - masing mikroba. Aktivitas yang terbentuk terlihat dari adanya zona hambat (zona bening) di sekitaran cakram dengan ukuran cakram (paper disc) $6 \mathrm{~mm}$, membuktikan bahwa ekstrak spons Ianthella basta yang diujikan menunjukkan kepekaan terhadap masing masing mikroba dan antibiotik yang digunakan sebagai kontrol positif.

Kontrol negatif yang digunakan yaitu metanol, terlihat dari hasil yang di peroleh metanol tidak menunjukkan adanya zona hambat pada pengujian yang dilakukan pada masing - masing mikroba uji. Hal ini sesuai dengan penelitian yang dilakukan oleh Wewengkang et al., (2014) dan Mujipradhana, (2018) membuktikan bahwa kontrol negatif metanol yang digunakan tidak berpengaruh pada uji antimikroba, sehingga daya hambat yang terbentuk tidak dipengaruhi oleh pelarut melainkan karena aktivitas senyawa yang ada dalam Spons Ianthella basta.

Berbalik dengan hasil yang ditunjukkan dari kontrol positif dari masing - masing mikroba uji terlihat kontrol positif menghasilkan aktivitas daya hambat yang besar dibandingkan dengan kontrol negatif. Kontrol positif yang digunakan yaitu kloramfenikol. Menggunakan kloramfenikol dikarenakan kloramfenikol merupakan antibiotik berspektrum luas. Hasil yang diperoleh bahwa pada bakteri Staphylococcus aureus menghasilkan daya hambat yang besar ditunjukkan dengan hasil yang diperoleh yaitu 18,05 $\mathrm{mm}$ dibandingkan dengan bakteri Eschericia coli, Pseudomonas aeruginosa dan Candida albicans. Hal ini dikarenakan antibiotik kloramfenikol lebih peka terhadap bakteri Staphylococcus aureus (Gram positif), kloramfenikol hanya membutuhkan konsentrasi 0,2-5 $\mu \mathrm{g} / \mathrm{mL}$, sedangkan pada kebanyakan bakteri gram positif bakteri dihambat pada konsentrasi 1-10 $\mu \mathrm{g} / \mathrm{mL}$ (Katzung, 2004).

Kriteria yang digunakan dalam penelitian ini untuk menggolongkan daya hambat dari kontrol uji dan bahan uji Spons Ianthella basta menggunkana kriteria kekuatan antibakteri menurut Davis dan Stout yaitu dapat dilihat pada tabel 3 dibawah ini:

\section{Tabel 3. Standar Kekuatan Daya}

\section{Antimikroba}

\begin{tabular}{c|c}
\hline $\begin{array}{c}\text { Diameter Zona } \\
\text { Bening (mm) }\end{array}$ & Kategori \\
\hline$>20$ & Sangat Kuat \\
\hline $10-20$ & Kuat \\
\hline $5-10$ & Sedang \\
\hline$<5$ & Lemah \\
\hline
\end{tabular}

Hasil ekstrak kasar etanol Spons Ianthella basta dari semua mikroba uji yaitu Escherichia coli, Staphylococcus aureus, Pseudomonas aeruginosa dan Candida albicans, terlihat yang memberikan daya hambat yang paling besar terdapat pada bakteri Staphylococcus aureus dengan jumlah rata - rata zona hambat yaitu $7,00 \mathrm{~mm}$ dengan kategori sedang. Hal ini menunjukkan bahwa ekstrak dari spons Ianthella basta 
memiliki daya hambat yang lebih peka pada Staphylococcus aureus dibandingkan Escherichia coli, Pseudomonas aeruginosa dan Candida albicans.

Perbedaan hasil aktivitas dari ekstrak Spons Ianthella basta terhadap mikroba uji selain senyawa yang terkandung dalam sampel dan kepekaan dari masing - masing Gram positif dan Gram negatif juga di pengaruhi oleh faktor lingkungan (habitat) dan lokasi pengambilan sampel. Bell dan Barnes (2003) juga menyatakan bahwa substrat tumbuh spons dapat berpengaruh terhadap morfologi spons, yang dengan demikian juga akan mempengaruhi bioaktivitasnya. Lingkungan perairan yang cenderung subur (terkontaminasi limbah organik) juga sangat berpengaruh besar terhadap produksi senyawa bioaktif spons. Hal ini disebabkan lingkungan yang subur dapat menyebabkan spons dapat mengurangi jumlah jenis dan kelimpahan simbion yang berasosiasi dengan spons tersebut (Steindler, 2002).

\section{KESIMPULAN}

Hasil penelitian yang diperoleh menunjukkan bahwa ekstrak kasar dari Spons Ianthella basta memiliki aktivitas antimikroba karena mampu menghambat pertumbuhan mikroba uji Staphylococcus aureus, Escherichia coli dan Candida albicans walaupun dengan zona hambat yang dikategorikan sedang.

\section{SARAN}

Perlu dilakukan penelitian lebih lanjut terhadap Spons Ianthella basta ke uji aktivitas lainnya agar dapat mengetahui manfaat lain selain aktivitas antimikroba.

\section{DAFTAR PUSTAKA}

Bell JJ, DKA Barnes. 2003. Effects of disturbance on assemblages: an example using Porifera. Biol Bull 205: 144-159.

Davis, W. W., T.R. Stout. 1971. Disc plate method of microbiological assay. Journal of microbiology. 22: 659665.

Dwijendra, I. M., D. S. Wewengkang., F. Wehantou. 2014. Aktivitas Antibakteri dan Karakterisasi Senyawa Fraksi Spons Lamellodysidea herbacea yang diperoleh dari Teluk Manado. Pharmacon. 3(4): 1-9.

Harborne, J. B. 1996. Metode Fitokimia: Penentuan Cara Modern Menganalisis Tumbahan. Diterjemahkan oleh Kosasih Padmawinata dan Iwang Soediro. ITB, Bandung.

Katzung., Betram G. 2004. Farmakologi dasar dan klinik edisi 4. Alih Bahasa: staf dosen farmakolgi fakultas kedokteran unviversitas sriwijaya. EGC, Jakarta : 709-719.

Kowal, A., Esther, A., Nickson, K., Kurniati, K., Henky, M., Deiske, H. 2018. Potensi antibakteri karang lunak lobophytum sp. Dari perairan pangalisang pulau bunaken terhadap bakteri Pseudomonas aeruginosa dan Staphylococcus aureus. Jurnal Ilmiah Platax. 6(2).

Kristanti, A. N., N.S. Aminah., M. Tanjung., B. Kurniadi. 2008. Buku Ajar Fitokimia. Unair Press, Surabaya.

Marnie L. Freckelton., Heidi M. Luter., Nikos Andreakis., Nicole S. Webster., Cherie A. Motti. 2011. 
Qualitative variation in colour morphotypes of Ianthella basta (Porifera: Verongida). Jurnal Hydrobiologia. Australian Institute of Marine Science. Australia.

Mpila, D. A. 2012. Uji Aktivitas Antibakteri Ekstrak Etanol Daun Mayana (Coleus atropurpureus benth) Terhadap Staphylococcus aureus, Escherichia coli dan Pseudomas aeruginosa Secara Invitro [skripsi]. Program Studi Farmasi FMIPA Universitas Sam Ratulangi, Manado.

Mujipradana, V.N., D. S. Wewengkang., E. Suryanto. 2018. Aktivitas Antimikroba dari Ekstrak Ascidian Herdmania momus pada Mikroba Patogen Manusia. Pharmacon. 7(3): 338-347.

Ortez, J. H. 2005. Disk Diffusion testing in manual of antimicrobial susceptibility testing. Marie B. Coyle (Coord. Ed). American society for Microbiology, America.

Romimohtarto, K. dan Juwana, S. 1999. Biologi Laut. Ilmu tentang Biota Laut. Pusat Penelitian dan Pengembangan Oseanologi- LIPI. Jakarta.

Steindler L, S Beer, M Ilan. 2002. Photosymbiosis in intertidal dan subtidal tropical sponges. Sybiosis: 33: $1-11$.

Sulastri, E., Cristadeolia, O.,Yusriadi., 2015. Formulasi Mikroemulsi Ekstrak Bawang Hutan dan Uji Aktivitas Antioksidan. Jurnal Pharmascience. 2(2): 2
Thakur, N.L., Müller W.E.G. 2004. Biotechnological potential of marine sponges. Current Science. 86(11).

Webster, N. S., M. W. Taylor, F. Behnam, S. Lu "cker, T. Rattel, S. Whalan, M. Horn \& M. Wagner, 2010. Deep sequencing reveals exceptional diversity and modes of transmission for bacterial sponge symbionts. Environmental Microbiology 12: 2070-2082.

Wewengkang, D., Deiske. S., Hengki. R. 2014. Karakterisasi dan bioaktif antibakteri senyawa spons Haliclona sp. dari teluk manado. Jurnal LPPM Bidang Sains dan Teknologi. 1(1). 